\title{
Reaction of new long-day pigeonpea genotypes to rust (Uredo cajani) ${ }^{1,2}$
}

\author{
Rodrigo Echávez-Badel ${ }^{3}$ and Angel Bosques-Vega ${ }^{4}$
}

\author{
J. Agric. Univ. P.R. 82(3-4):201-208 (1998)
}

\begin{abstract}
Five long-day pigeonpea [Cajanus cajan (L.) Millsp.] genotypes were ovaluated for fleld resistance to rust (Uredo cajani) with seven planting dates per year during 1992, 1993 and 1994 at the lsabela Substation of the University of Puerto Rico, Mayagulez Campus. Rust was a trequent problem over the three-year testing period but less serlous when plgeonpea was planted in February. Planting date had a significant effect on the intensity of rust and the fleld reaction. For all genotypes, the effect of years was the same for disease reaction and different for infection intensity. Long-day genotypes showed levels of intermediate res/stance to moderate susceptiblity. The average rust infection of early maturlng 1-8-2, with largest pustule sizes (rated as moderately susceptible) was signiflcantly greater $(P<\mathbf{0 . 0 5})$ than that of Iate-maturing II-56 (intermediate). The remaining late maturing I13, 1-58-3 and early genotype I-58-1 also had intermediate resistance to rust, but pustule sizes were greater than those observed on II-56. It is evident that distinct host varlation exlsted among long-day pigeonpea genotypes for level of susceptiblity or relative resistance to $U$. cajani.
\end{abstract}

Key words: pigeonpea, long-day genotype, rust, Intermedlate resistance, moderate susceptibility

\section{RESUMEN}

Reacción de nuevos genotipos de gandul de días largos a la roya (Uredo cajani)

Se evaluaron clnco genotipos de gandul [Cajanus cajan (L.) Milisp.] de días largo para resistencia de campo a la roya (Uredo cajani) en siete épocas de siembra por afio, durante el 1992, 1993 y el 1994 en la Subestación de Isabela de la Universidad de Puerto Rico, Recinto de Mayagüez. La roya se manlfestó con frecuencia durante los tres años de experimentación, pero no fue un problema serio cuando los genotipos se sembraron en tebrero. La época de slembra tuvo un efecto signiflcativo en la Intensidad de la roya y en la reacción de campo de los genotipos probados. El efecto de los ańos fue el mismo para la reacción a la enfermedad, pero diferente para la intensidad de infección. Los genotipos mostraron niveles de resistencla intermedia a susceptlbilidad moderada. La infección de roya del genotipo de madurez

${ }^{3}$ Manuscript submitted to Editorial Board 15 December 1997.

The authors are indebted to Ratil Macchiavelli for assistance with statistical analysis. Thanks are extended to Linda Beaver and Rocío Rodriguez for reviewing and providing helpful comments on the manuscript.

'Researcher in Plant Pathology, Crop Protection Department, Agricultural Experiment Station, College of Agricultural Sciences, Mayagiez Campus, University of Puerto Rico, Mayagtez, P.R. 00681-9030.

${ }^{4}$ Assistant Researcher, Horticulture Department. 
temprana 1-8-2 caracterizada por las pústulas más grandes (evaluado como moderadamente susceptlble), fue significatlvamente mayor $(P<0.05)$ que la del genotlpo tardío II-56 (intermedio). Los restantes genotipos tardios I-13, I58-3 y temprano 1-58-1 tamblén mostraron niveles de resistencla intermedia a la roya, pero el tamańo de las pústulas fue mayor que el encontrado en II56. Es evidente que hay varlablildad entre los genotipos de días largos en los niveles de susceptibilidad o resistencla relativa a $U$. cajani.

\section{INTRODUCTION}

Pigeonpea [Cajanus cajan (L.) Millsp.] is a perennial shrub grain legume which offers the consumer a healthy food rich in protein and fiber. In Puerto Rico and the Caribbean, it is harvested green and used for fresh market or canned. In spite of the fact that pigeonpea production has decreased more than $27 \%$ in Puerto Rico in recent years, this crop contributes $4 \%$ to the gross income generated by vegetables and legumes (Departamento de Agricultura, 1995). In Puerto Rico, pigeonpeas are cultivated on small farms for home consumption or for the local market.

The first symptoms of pigeonpea rust (Uredo cajani) are the presence of small chlorotic spots on the lower leaf surface that later turn into reddish brown pustules (uredia) surrounded by either chlorotic or necrotic halos. One pustule contains thousands of urediospores and severe infections can cause defoliation (Whiteman et al., 1985). Kannaiyan et al. (1981) reported that rust is a foliar disease which does not threaten commercial pigeonpea plantings in Puerto Rico, but when environmental conditions are favorable this pathogen can cause defoliation and low yields. Rust has been reported as a major foliar disease in Puerto Rico (Abrams et al., 1978), especially at Isabela (Rodríguez and Meléndez, 1984), possibly due to frequent plantings with susceptible cultivars and favorable conditions for disease development.

At the moment, germplasm with high resistance to rust is not available in Puerto Rico. However, the International Crops Research Institute for Semi-Arid Tropics (ICRISAT) in India has identified germplasm resistant to rust that could be used (D. V. R. Reddy, personal communication). The pigeonpea breeding program of the Agricultural Experiment Station (AES), UPR, has developed long-day genotypes with the potential to reduce production costs and extend the harvest season alternating with short-day genotypes. The objective of this research was to evaluate five promising long-day pigeonpea genotypes for field resistance to rust at Isabela, Puerto Rico.

\section{MATERIALS AND METHODS}

Field experiments were established at the Isabela Substation during 1992, 1993 and 1994 using five promising long-day pigeonpea 
genotypes: I-8-2, I-13, I-58-1, I-58-3 and II-56. Genotypes I-8-2 and I58-1 are early maturing, whereas I-13, I-58-3 and II-56 are late maturing. Genotypes were planted in a randomized complete block design with four replications at seven planting dates per year, beginning in February and ending in August. Crop cycles ranged from four to six months, depending on the genotype and planting date (cycle tends to be shorter in late plantings). Plot size consisted of two rows $0.9 \mathrm{~m}$ apart and $4 \mathrm{~m}$ long $\left(7.3 \mathrm{~m}^{2}\right)$ with 26 plants per plot. A rust susceptible check was not included because in the pigeonpea program long-day susceptible genotypes have not been identified. Because rust severity increases with the onset of flowering (Reddy et al., 1993), genotypes were evaluated between pre-flowering and pod set stages (three, four and five months after planting). The average of three readings was used as criterion. The rust scoring guide (IPO \& CIMMYI, 1984) was modified slightly and was based on infection intensity (1 to approximately $30 \%$ of total real leaf area covered by pustules) and field reaction (pustule size) recorded from 1 to $5: 1.0$ to $1.4=R$ (resistant), visible chlorosis or necrosis, no uredia present; 1.5 to $2.4=M R$ (moderately resistant), small uredia surrounded by either chlorotic or necrotic areas; 2.5 to 3.4 = I (intermediate), variable sized uredia, some with chlorosis, necrosis, or both; 3.5 to 4.4 = MS (moderately susceptible), medium sized uredia possibly surrounded by chlorotic areas; and 4.5 to $5=\mathrm{S}$ (susceptible), large uredia, generally with little or no chlorosis or no necrosis. An analysis of variance was performed for disease infection for each year and combined over three years. Means were separated by Tukey's test.

\section{RESULTS AND DISCUSSION}

Rust was a frequent problem over the three-year testing period at the Isabela Substation. Overall the disease was less serious in the February planting than in the remaining plantings of the year (Figure 1). Rust infection was relatively low in 1992 and 1993, and high in 1994 (Figure 2).

The interaction genotype $x$ planting date was significant at $\mathrm{P}<0.05$ for infection intensity (Figure 1). That is, planting date had a signifcant effect on rust infection intensity. All genotypes had the lowest infection in February and the highest in May planting, with the exception of I-8-2. This genotype had the highest infection in March (Figure 1). Planting date had a significant effect on rust pustule sizes. The interaction genotype $\times$ planting date for field reaction was caused by the consistent susceptibility of I-8-2 over planting dates in contrast to that of the other genotypes, which had a more variable reaction over dates (Figure 3). Generally, in the August planting all genotypes tended to 


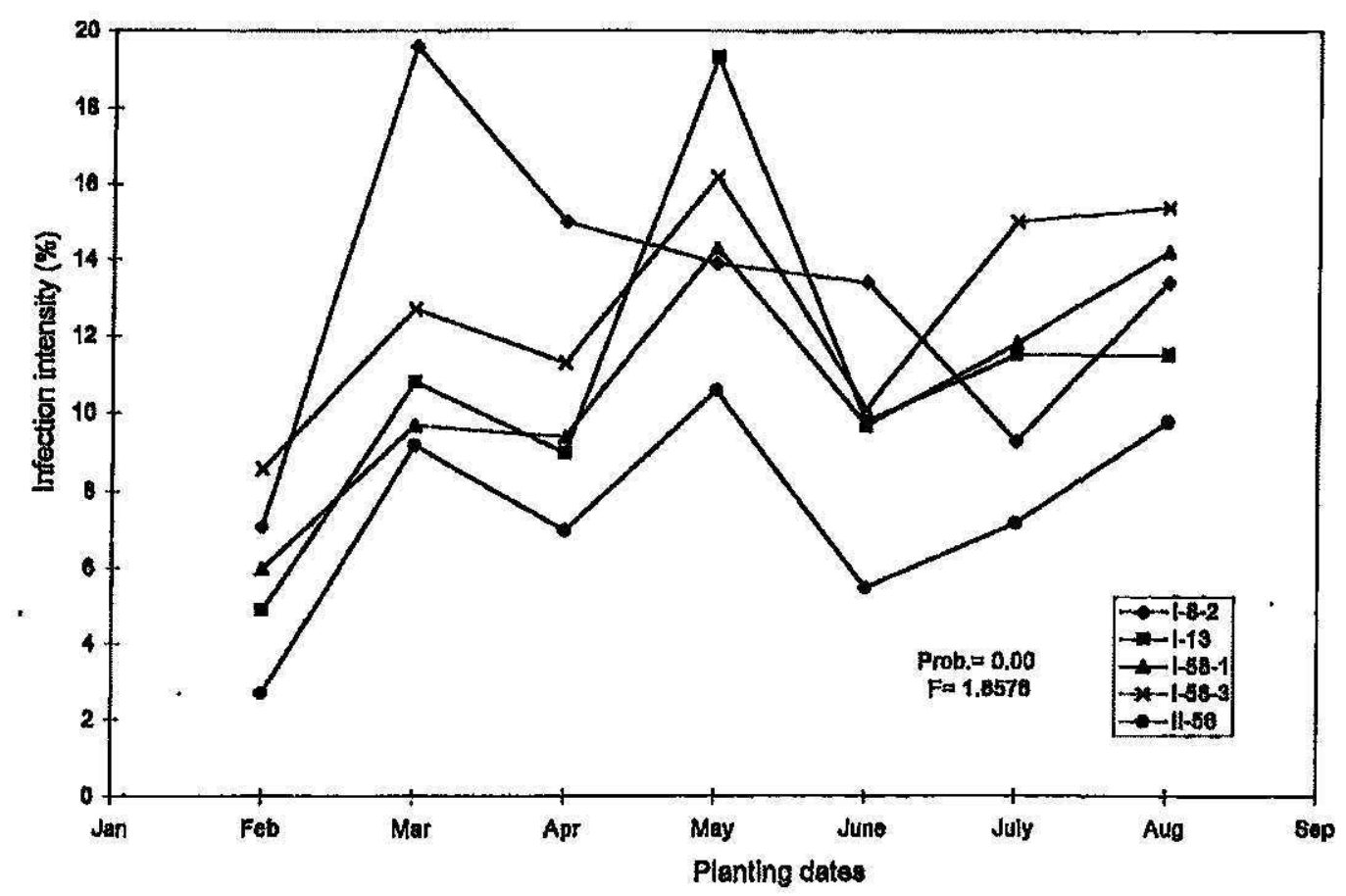

FrGURE 1. Interaction genotype $x$ planting dates for infection intensity of pigeonpeas over three years at Isabela, Puerto Rico.

have the largest pustule size (Table 2). The interaction between genotype and year was significant at $\mathrm{P}<0.05$ for intensity infection (Figure 2); that is, the effect of year was different in all genotypes. All pigeonpeas, except I-8-2, showed higher infection intensity in 1992 than in 1993 (Figure 2). However, the interaction genotype $\times$ year for field reaction was not significant $(F=1.10$, Prob $=0.3631)$; that is, the difference among years was the same in all genotypes.

The average infection intensity of II-56 (7.4\%) was lower than that of I-8-2 (13.1\%), I-13 (12.1\%), I-58-1 (10.7\%), and I-58-3 (12.8\%) (Table 1). Long-day genotypes showed levels of intermediate resistance to moderate susceptibility. In spite of the fact that none of the genotypes showed a resistant reaction to rust at all planting dates, II-56 had a pustule rating average of 2.6 , considered an intermediate field reaction. Furthermore, this pustule size is smaller than that of I-13 (3.0), I58-1 (2.9) and I-58-3 (3.2), also rated as intermediate, and smaller than that of I-8-2 (3.8), rated as moderately susceptible (Table 2). Rust field reaction of I-8-2, with largest pustule sizes, was significantly greater $(P$ $<0.05)$ than that of late-maturing II-56 for most planting dates, with the exception of February and August. The susceptible reactions of I-82 , an early maturing genotype, could be due either to the fact that evaluations were made during the later period of the crop cycle, or that it 


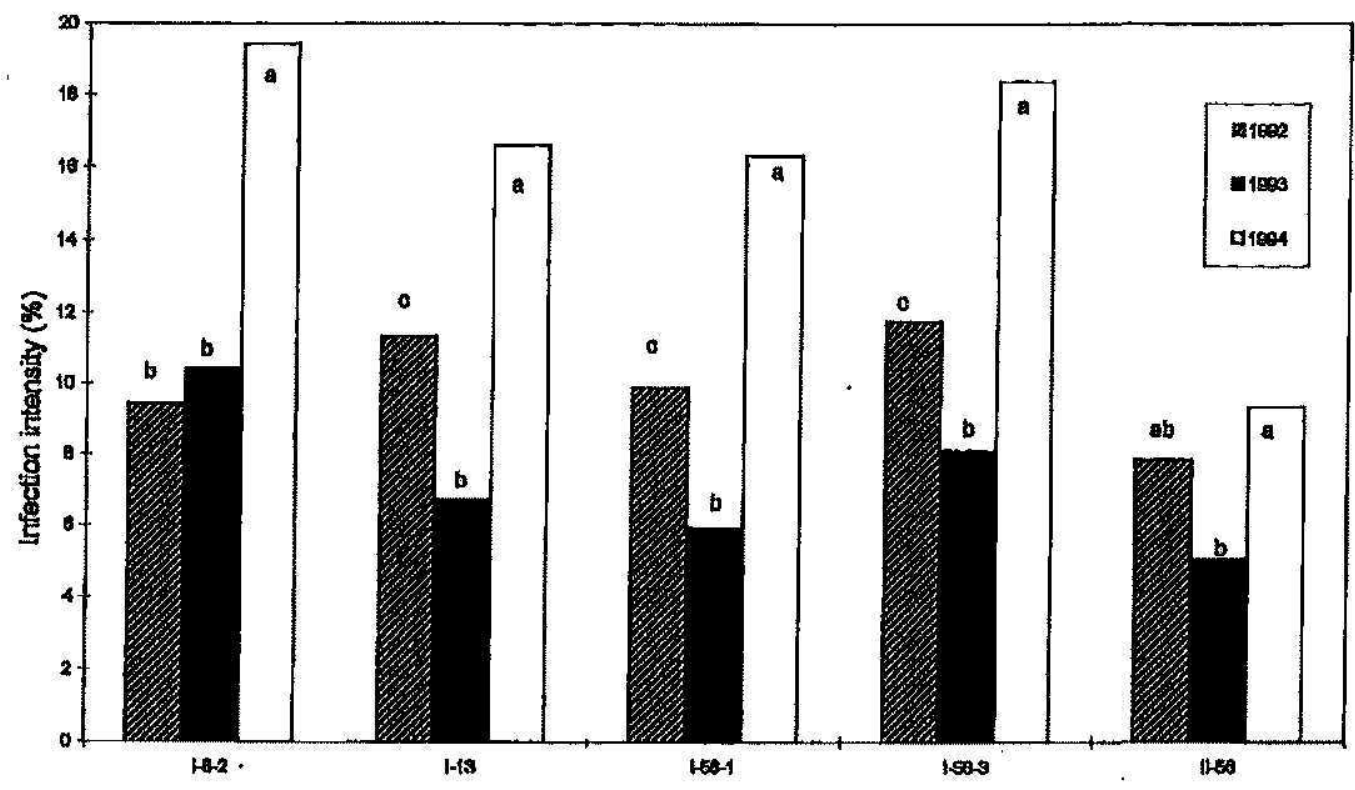

Yoars wils the same letter for each genotype do not differ slgnificantly acoording to Tukey's test (P<0.06)

FIGURE 2. Interaction genotype $\times$ year for infection intensity of five pigeonpea genotypes evaluated over three years at Isabela, Puerto Rico.

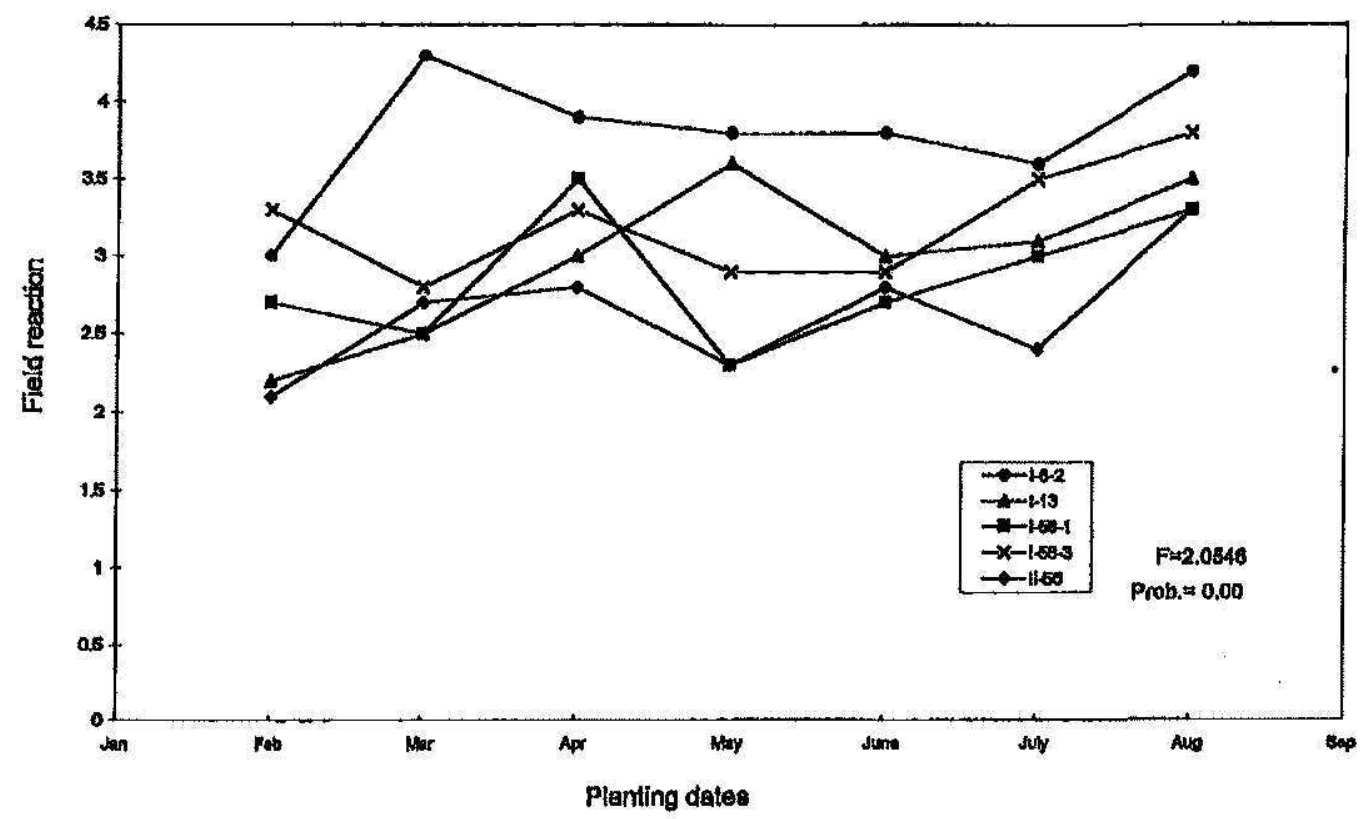

FigURE 3. Interaction genotype $\times$ planting dates for rust field reaction of pigeonpeas over three years at Isabela, Puerto Rico. 
TABLE 1.-Rush infection intensity (II) of Long-day pigeonpeas sown at different planting dates over 3-year evaluation at Isabela, Puerto Rica.

\begin{tabular}{|c|c|c|c|c|c|c|c|c|}
\hline Genotype & $\begin{array}{c}\text { February } \\
\text { II }(\%)^{2}\end{array}$ & $\frac{\text { March }}{\text { II (\%) }}$ & $\begin{array}{l}\text { April } \\
\Pi(\%)\end{array}$ & $\begin{array}{l}\text { May } \\
\text { II (\%) }\end{array}$ & $\begin{array}{l}\text { June } \\
\text { II (\%) }\end{array}$ & $\begin{array}{l}\text { July } \\
\Pi 1(\%)\end{array}$ & $\begin{array}{l}\text { August } \\
\Pi 1(\%)\end{array}$ & $\begin{array}{c}\text { Average } \\
\text { III (\%) }\end{array}$ \\
\hline I-8-2 & $7.1 \mathrm{a}^{2}$ & $19.6 \mathrm{a}$ & $15.0 \mathrm{a}$ & $13.9 \mathrm{ab}$ & $13.4 \mathrm{a}$ & $9.3 \mathrm{ab}$ & $13.4 \mathrm{a}$ & 13.1 \\
\hline I-13 & $4.9 a$ & $10.8 \mathrm{~b}$ & $9.0 \mathrm{ab}$ & $19.3 \mathrm{a}$ & $9.8 \mathrm{ab}$ & $15.5 \mathrm{ab}$ & $15.5 \mathrm{a}$ & 12.1 \\
\hline I-58-1 & $6.0 \mathrm{a}$ & $9.7 \mathrm{~b}$ & $9.4 \mathrm{ab}$ & $14.3 \mathrm{ab}$ & $9.7 \mathrm{ab}$ & $11.8 \mathrm{ab}$ & $14.2 \mathrm{a}$ & 10.7 \\
\hline I-58-3 & $8.6 \mathrm{a}$ & $12.7 \mathrm{~b}$ & $11.3 \mathrm{ab}$ & $16.2 \mathrm{ab}$ & $10.1 \mathrm{ab}$ & $15.0 \mathrm{a}$ & $15.4 \mathrm{a}$ & 12.8 \\
\hline II-56 & $2.7 \mathrm{a}$ & $9.2 \mathrm{~b}$ & $7.0 \mathrm{~b}$ & $10.6 \mathrm{~b}$ & $5.5 \mathrm{~b}$ & $7.2 \mathrm{~b}$ & $9.8 \mathrm{a}$ & 7.4 \\
\hline Means & 5.9 & 12.4 & 10.3 & 14.9 & 9.7 & 11.8 & 11.7 & \\
\hline
\end{tabular}

'III = Infection intensity (\%): 1 to approximately $30 \%$ of total real area covered by pustules.

¿Values in columns followed by the same letter do not differ significantly at $\alpha=0.05$ according to Tukey's test. 
TABLE 2.-Rust field reaction (FR) of long-day pigeonpeas sown at different planting dates over three years at Isabela, Puerto Rico.

\begin{tabular}{|c|c|c|c|c|c|c|c|c|}
\hline Genotype & $\begin{array}{c}\text { February } \\
\mathrm{FR}^{1}\end{array}$ & $\underset{\text { FR }}{\text { March }}$ & $\underset{\text { April }}{\text { Ap }}$ & $\begin{array}{l}\text { May } \\
\text { FR }\end{array}$ & $\begin{array}{c}\text { June } \\
\text { FR }\end{array}$ & $\begin{array}{l}\text { July } \\
\text { FR }\end{array}$ & $\begin{array}{l}\text { August } \\
\text {. FR }\end{array}$ & $\begin{array}{c}\text { Average } \\
\text { FR }\end{array}$ \\
\hline I-8-2 & $3.0 \mathrm{ab}^{2}$ & $4.3 \mathrm{a}$ & $3.9 \mathrm{a}$ & $3.8 \mathrm{a}$ & $3.8 \mathrm{a}$ & $3.6 \mathrm{a}$ & $4.2 \mathrm{a}$ & 3.8 \\
\hline I-13 & $2.2 \mathrm{~b}$ & $2.5 \mathrm{~b}$ & $3.0 \mathrm{ab}$ & $3.6 \mathrm{a}$ & $3.0 \mathrm{ab}$ & $3.5 a b$ & $3.5 \mathrm{a}$. & 3.0 \\
\hline I-58-1 & $2.7 \mathrm{ab}$ & $2.5 \mathrm{~b}$ & $3.5 \mathrm{ab}$ & $2.3 \mathrm{~b}$ & $2.7 \mathrm{~b}$ & $3.0 \mathrm{ab}$ & $3.3 \mathrm{a}$ & 2.9 \\
\hline I-58-3 & $3.3 \mathrm{a}$ & $2.8 \mathrm{~b}$ & $3.3 \mathrm{ab}$ & $2.9 \mathrm{ab}$ & $2.9 \mathrm{ab}$ & $3.5 \mathrm{a}$ & $3.8 \mathrm{a}$ & 3.2 \\
\hline I-56 & $2.1 \mathrm{~b}$ & $2.7 \mathrm{~b}$ & $2.8 \mathrm{~b}$ & $2.3 \mathrm{~b}$ & $2.8 \mathrm{~b}$ & $2.4 \mathrm{~b}$ & $3.3 \mathrm{a}$ & 2.6 \\
\hline Means & 2.7 & 3.0 & 3.3 & 3.0 & 3.0 & 3.2 & 3.6 & \\
\hline
\end{tabular}

IFR = Field reaction: Resistant $(R)=1.0$ to $1.4 ;$ Moderately Resistant $(M R)=1.5$ to 2.4 ; Intermediate $(T)=2.5$ to 3.4 ; Moderately Susceptible (MS) $=3.5$ to 4.4 ; Susceptible $(\mathrm{S})=4.5$ to 5.0 .

2Values in columns followed by the same letter do not differ significantly at $\alpha=0.05$ according to Tukey's test. 
is a susceptible genotype. It is important to note that the crop cycle of long-day pigeonpeas tested is shorter in late plantings. Furthermore, I-8-2 is 15 days earlier than most pigeonpeas, with the exception of the I-58-1 genotype. First author has occasionally observed early severe rust infection and defoliation of I-8-2 pigeonpea in other trials conducted at Isabela. Further experiments with I-8-2 are contemplated to confirm its rust susceptibility. It is evident that distinct host variation existed among long-day pigeonpea for level of susceptibility or relative resistance to U. cajani.

Among five promising long-day pigeonpea genotypes tested and other genotypes available in the AES, UPR, there is no source of high resistance to $U$. cajani. It is necessary to locate additional sources of rust resistance by screening new genetic materials from ICRISAT and to incorporate this resistance into our promising pigeonpea genotypes. The development of commercial pigeonpea cultivars with rust resistance will benefit farmers of Puerto Rico by providing increased production of this important grain legume crop.

\section{ITTERATURE CTMED}

Abrams, R., A. Morales and F. J. Julia, 1978. Status of research on pigeonpea in Puerto Rico. Trop. Grain Legume Bull, 11-12:17-21

Departamento de Agricultura, 1995. Ingreso Bruto Agricola de Puerto Rico 1994/1995. Oficina de Estadísticas Agricolas. Gobierno de Puerto Rico. Santurce, P.R. p. 18.

Kannaiyan, J., Y. L. Nene, M. V. Reddy and T. N. Raju, 1981. International Survey of Pigeonpea Diseases. International Crop Research Institute for the Semi Arid Tropics (ICRISAT).

Reddy, M. V., T. N. Raju, S. B. Sharma, Y. L. Nene and D. McDonald, 1993. Handbook of pigeonpea diseases. Information Bulletin No. 42, International Crops Research Institute for the Semi-Arid Tropics, Patancheru, Andhra Prades 602924, India. p.61.

Research Institute for Plant Protection (IPO), Wageningen, The Netherlands and the International Maize and Wheat Improvement Center (CMMMYT), 1984. Rust Scoring Guide. Mexico. p.11.

Rodriguez, R. and P. L. Meléndez, 1984. Field screening of pigeonpea (Cajanus cajan) for resistance to foliax diseases in Puerto Rico. J. Agric. Univ. P.R. 68:275-279.

Whiteman, P. C., D. E. Byth and E. S. Wallis, 1985. Pigeonpea [Cajanus cajan (L.) Millsp.]. In: Grain Legume Crops. R. J. Summerfield and E. H. Roberts (Ed.) ICRISAT, India. $859 \mathrm{pp}$. 